\title{
Career Success Studies: An Examination of Indicators, Approach and Underlying Theories in Literature
}

\author{
Shahibudin Ishak \\ School of Business Management, College of Business, Universiti Utara Malaysia, Sintok, Kedah Darul Aman, Malaysia \\ Email address: \\ shahibudin@uum.edu.my
}

\section{To cite this article:}

Shahibudin Ishak. Career Success Studies: An Examination of Indicators, Approach and Underlying Theories in Literature. Science Journal of Business and Management. Vol. 3, No. 6, 2015, pp. 251-257. doi: 10.11648/j.sjbm.20150306.16

\begin{abstract}
Many theories have been identified as underpinning theories for study career success. Therefore, this paper has aimed to reveal overview career success concept, indicators, approach and the theories underpinning to study career success. The main purpose of this paper is to review relevant literatures relate to career success theories. This paper compares contemporary career theory with the theory applied in recent career success research. The research makes inconsistent use of career theory and in particular neglects the interdependence of the objective and subjective careers. The paper offers new guidelines for bringing about an agreement between career theory and career success research. Most of the study framework is based on theories that become evidence in literature is reported. This paper contributes to the literature by examine the different types of career theories fit on career success research.
\end{abstract}

Keywords: Career Success, Career Theories, Career Approach, Career Indicators

\section{Introduction}

The concept of career success is still and increasingly becoming a popular research topic in the field of management from 1980 s to 2015 [33, 34, 35, 36, 37]. It research become more complex because of career concept is not a single theoretical underpinning or single disciplinary approach. The aim of this paper is to briefly identifying concepts, indicators, approach and the underpinning theories that have shape the empirical research in career study since the last 30 years using historical review methods. This historical review of career research is for the period 19852015. The review is aim to answer the following questions:

RQ1: What are the indicators of career success?

RQ2: What approach has been used to study career success?

RQ3: What are the theories that have shaped career research from 1980s to 2015 ?

Career success is a way for individuals to fulfill their needs for achievement and power in career path. Generally, research on career success will benefits individuals and organizations. At the individual level, career success refers to the acquisition of materialistic advancement, power, and satisfaction [1]. Thus, knowledge of career success helps individuals to develop appropriate strategies for career development [2]. At the organizational level, knowledge of the relationship between individual difference and career success helps human resource managers design effective career systems [1].

Career success is conceptualized as an outcome in terms of the objective and subjective elements of achievement through an individual's career experiences [3, 4]. Generally, career success often involves a promotion in organizational hierarchy, a rise in salary, an increase in power, a broad job responsibility, and a feeling of satisfaction with the career. In particular, career success has been defined as "the real or the perceived positive psychological out-comes and work related achievements one has accumulated as a result of one's work experiences" [2, 5]. Similarly, Melamed [6] defined career success as "the subjective and objective aspects of achievement and progress of an individual through an organization or occupation." However, career success is an evaluative concept where the judgments of career success depend on who does the judging [1].

\section{Indicators of Career Success}

Previous studies revealed that there was no single measure of career success. Therefore, there are different career success indicators for different jobs. Table 1 shows the career 
success indicators samples for individuals that have been used in the previous studies from 1988 to 2015 . Consistent with recent studies, career success has been constructed into objective and subjective dimensions [3, 7, 8]. Career success also can be subdivided into two different components [9] in terms of external or extrinsic components. For example, external component consists of an employee's salary level, total compensation, salary progression, the number of promotions, and the internal or intrinsic components (the employee's job, career, and life satisfaction levels). Researchers have agreed that, in order to investigate career success, both dimensions of career success (extrinsic/intrinsic or objective/subjective) should be studied together $[3,10]$. Based on this dimensions, four quadrants of career success have been proposed [40].

Q1

(Extrinsic/Objective)

External visibility, can be observed: Hierarchical rank, number of promotion, job changes, salary

\section{Q2}

(Extrinsic/Subjective)

External visibility, instrumental value judged by oneself or others:

assessments of promotability and employability; perceived career opportunities; satisfaction with pay/promotion

Thus, career scholars proposed multidimensional model of career success and always tested in career success studies. Quantitative and qualitative measures methods begun to be used to investigate individual career success using four quadrants of career success typology.

Table 1. Sample of Career Success Indicators.

\begin{tabular}{ll}
\hline Career success indicators & Authors (year) \\
\hline Job success & \\
$\begin{array}{l}\text { Interpersonal success } \\
\text { Life success financial success }\end{array}$ & Gattiker \& Larwood (1988) [11] \\
$\begin{array}{l}\text { Hierarchical success } \\
\text { Job and career satisfaction }\end{array}$ & \\
$\begin{array}{l}\text { Compensation } \\
\text { Number of promotions }\end{array}$ & Judge et al. (1995) [1] \\
$\begin{array}{l}\text { Remuneration / promotion } \\
\text { Employability }\end{array}$ & \\
Work satisfaction & \\
Career satisfaction & \\
Life satisfaction & \\
$\begin{array}{l}\text { Promotion and pay } \\
\text { Result in career }\end{array}$ & Boudreau et al. (1999) [9] \\
Income; & Seibert et al. (2001) [5] \\
\hline
\end{tabular}

\begin{tabular}{|c|c|}
\hline Career success indicators & Authors (year) \\
\hline \multicolumn{2}{|l|}{ Achievement } \\
\hline \multicolumn{2}{|l|}{ Career satisfaction } \\
\hline \multicolumn{2}{|l|}{ Social status } \\
\hline \multicolumn{2}{|l|}{ Reputation } \\
\hline Recognition & Lau \& Shaffer (1999) [12] \\
\hline \multicolumn{2}{|l|}{ Salary } \\
\hline \multicolumn{2}{|l|}{ Number of promotions } \\
\hline Career satisfaction & $\mathrm{Ng}$ et al. (2005) [14] \\
\hline \multicolumn{2}{|l|}{ Salary } \\
\hline \multicolumn{2}{|l|}{ Number of promotions } \\
\hline Career satisfaction & Byrne, Dik, \& Chiaburu (2008) [16] \\
\hline \multicolumn{2}{|l|}{ Monthly salary } \\
\hline \multicolumn{2}{|l|}{ Hierarchical status } \\
\hline Career satisfaction & Abele \& Spurk (2009) [15] \\
\hline \multicolumn{2}{|l|}{ Total compensation } \\
\hline \multicolumn{2}{|l|}{ Total promotions } \\
\hline \multicolumn{2}{|l|}{ Career satisfaction } \\
\hline Life satisfaction & Todd et al. (2009) [17] \\
\hline \multicolumn{2}{|l|}{ Salary Level } \\
\hline \multicolumn{2}{|l|}{ Total Job promotions } \\
\hline \multicolumn{2}{|l|}{ Career satisfaction } \\
\hline Life satisfaction & Ishak, S (2011) [32] \\
\hline \multicolumn{2}{|l|}{ Number of promotion } \\
\hline \multicolumn{2}{|l|}{ Salary } \\
\hline Career satisfaction & Cheramie, R. (2013) [38] \\
\hline \multicolumn{2}{|l|}{ Salary level } \\
\hline Career satisfaction & Hennekam, S. (2015) [39] \\
\hline
\end{tabular}

\section{Approach of Career Success Studies}

A literature review revealed that, over time, three approaches to studying career success have been identified. These three approaches are: (a) the individual perspective, (b) the structural perspective, and (c) the behavioral perspective [2].

The individual approach focuses on individual variables such as human capital, socio demographic status, stable individual differences, and motivational factors. The individual variables approach states that the individual is the one who develops their own human capital and, therefore, maximizes their education and skill investments for achieving success in their career [3].

The structural approach is based on the management theory and vacancy models and it suggests that organizational factors such as organizational size and internal promotional practices are prerequisites for successful individual careers in organizations [3].

The behavioral approach assumes that career achievement is a function of certain career strategies including political influence, behavior, and organizational sponsorship [3].

\section{Underlying Theories of Career Success Studies}

Several theories have been found to serve as the theoretical basis underpinning the study of career success in literature 
(Table 2). However, it is found that large numbers of the past research studies investigated career success using variables without considering the theoretically based variables [1]. Review of the literature since 1980 s, revealed some of the popular theories that underpinning the career success studies.

\subsection{Human Capital Theory}

The most common theory specifically addressing career success in the literature is the human capital theory [18]. The human capital theory dominates the management literature of career success since 1980s [1, 2, 5, 6, 19, 33]. This theory hypothesizes that everyone differs in the amount and quality of human asset or capital in terms of education, experience, skill, and personal characteristics that they bring to the job. The amount and effectiveness of the human capital one has and expends on the job is the main determinant of career success. The human capital theory proposes that employees make rational choices regarding investments in their own human capital. This theory argues that individuals make rational choices regarding whether or not they want to invest more time, effort, and money in education, training, and experience [18]. Their investment in these human capitals influences their work performance and, subsequently, influences the organization rewards. Melamed [6] classified human capital into three types: (a) relevant to the job (e.g. education, experience, mental ability); (b) partially relevant depending on the nature of the job (e.g. personality); and (c) not relevant to the job at all (e.g. race, marital status, physical appearance).

\subsection{Social Capital Theory}

Some researchers apply Social Capital Theory as theoretical basis for study career success [5, 31, 34]. Social Capital Theory is defined as investment of resources such as trust, norms, and networks inherent in social relations with expected returned [21]. Nikitkov and Sainty study [31] provides empirical support for the value of social networking as a proxy for the development of social capital, support in establishing the link between a group of social network profile characteristics and one's career success. Roziah Mohd Rasdi, Thomas N. Garavan, Maimunah Ismail [34] in their study proved that networking significantly related to career success.

\subsection{Career Congruence Theory}

Some researchers apply the Career Congruence Theory by Holland [20] as their theoretical basis. In this theory Holland stated that individuals are attracted to a particular occupation that meets their personal needs and provides them satisfaction. Therefore, an individual's personality and his or her vocational choice are related to career choice [20]. To be successful and satisfied in one's career, it is necessary to choose an occupation that is congruent with one's personality. Vocational satisfaction and achievement depend on the congruence between personality and environment factors. Holland's theory has provided a basis for linking personality and vocational behavior and it is based on three assumptions.

The first assumption is that persons can be categorized under six different personality types and environments: (a) Realistic types (involves tangible or physical activities), (b) Investigative types (involves activities requiring thinking, organizing, and understanding), (c) Artistic types (involves self-expression or artistic creation), (d) Social types (involves interpersonal activities), (e) Enterprising types (involves verbal activities to influence others or to attain power and status), and (f) Conventional types (involves rule-regulated activities). This is called the RIASEC model [20]. The second assumption is that people search for environments that will let them exercise their skills and abilities, express their attitudes and values, and take on agreeable problems and roles. The third assumption of Holland's theory is that behavior is determined by an interaction between personality and environment.

\subsection{Super's Theory of Vocational Choice}

With regard to the career stage, a few researchers have used Super's theory as a theoretical basis [22]. Super's theory of Vocational Choice proposed four career development stages: (a) exploration, (b) establishment, (c) maintenance, and (d) disengagement. Each stage is marked by distinctive attitudes, motivations, and behaviors that occur in sequence over career development. Super later suggested that career stages are not tied to chronological age and that recycling across stages is normal.

In the same way, according to classical models of career stages such as Hall's [23], individuals evolve in their careers through a series of steps: (a) trial and exploration (until about age 25), (b) growth and establishment (until the 40s), then maintenance, and (c) decline (after the 50s). According to Hall, career stages are generally linked closely to biological age. Each stage is characterized by a set of tasks and roles and is distinct in terms of its associated needs, motivations, attitudes, and behaviors (satisfaction, performance, and involvement). Previous research by Byrne et al. [16] proposed that career stages moderate the relationship between predictors and career outcomes. Generally, the relationship between leadership behaviors and career outcome vary as a function of career stage.

\subsection{The Mobility Theory}

Another theoretical basis that has been used to explain career success is the mobility theory [30, 35]. Turner [24] proposed the career mobility theory to explain the promotion system in a career. There are two systems of upward mobility (job promotions) in an organization: contest mobility and sponsored mobility. The contest mobility system needs people to compete for upward mobility. This perspective argues that an individual still has the chance to win the competition in the end by devoting time and energy. According to the contest-mobility promotion, the investments in human capital should result in increased rewards, salary, 
and promotion. In contrast, sponsor-mobility systems permit only those who have been chosen by the powerful to get upward mobility. This perspective suggests that special attention was given to those who have a high potential and provided sponsoring activities to help them win the competition. $\mathrm{Ng}$ et al. [14] suggested that this mobility theory is useful in understanding employees' career success.

\subsection{Social Learning Theory (SLT)}

With regard to the relationship between behavior and career success, some researchers have applied the social learning theory (SLT) as their theoretical basis. The SLT suggests that people learn new behaviors through reinforcement or punishment or through the observation of social factors in their environment. It also proposes a combination of environmental (social) and psychological factors that influence behavior. If people observe positive, desired outcomes in an observed behavior, they are likely to model, imitate, and adopt the behavior [25]. Based on the social learning theory by Bandura, Lau and Shaffer [12] suggested that certain personality traits have an influence on career success even in incongruent situations because people can actively learn and modify their personality or behavior. Personality attribute characteristics in terms of high expectations or beliefs to acquire preferred career outcomes are postulated to be the determinants of career success.

\subsection{Social Cognition Career Theory (SCCT)}

Another theory addressing career success is the Social Cognition Career Theory (SCCT) proposed by Lent, Brown, and Hackett [26]. The SCCT was extended in 2000 based on Bandura's social cognitive theory. The social cognitive theory (SCT) stemmed from the social learning theory. SCT asserts that human behavior is uniquely determined by dynamic, reciprocal interaction among three factors: (a) personal attributes, (b) behavior, and (c) environment. Self-efficacy can influence what individuals do with the knowledge and skills they possess. Although the SCCT theory takes Bandura's SCT and connects it to career related choices, plans, performance behaviors, and explorations, the SCCT focuses on the connection of selfefficacy, outcome expectations, and personal goals that influence an individual's career choice. According to Lent et al., the SCCT posits that the cognitive-personal variables of self-efficacy beliefs, career outcome expectations, and career goals (intentions, plan, or aspiration to engage in a particular career direction) are key mechanisms in career development. Career choice is influenced by the beliefs the individual develops and is refined through four major sources: (a) personal performance accomplishments, (b) vicarious learning, (c) social persuasion, and (d) physiological states and reactions. As a result, one is likely to develop goals that involve his or her continuing involvement in that activity.

The SCCT outlines the three interlocking processes by career interest, career relevant choice and actions, and levels of career performance attainment. Two aspects of career attainment are: (a) the level of individual attainment in their work tasks (e.g. promotion, salary) and (b) the degree to which they persist at a particular work activity (e.g. job satisfaction). There are feedback loops between performance attainment and learning experience. Hence, SCCT provides a useful model for understanding the phenomenon of individual career success [27].

Previously, Roziah Mohd Rasdi, et al.[27] developed a theoretical framework for measuring public sector managers' career success using SCCT. They proposed four factors (individual, organizational, managerial competencies, and the person-environment fit) that predict the potential of managers' career success. Furthermore, Abele and Spurk's longitudinal study [15] supported the SCCT theory in explaining career success. They found that occupational selfefficacy and career advancement goals had an impact on objective and subjective career attainments.

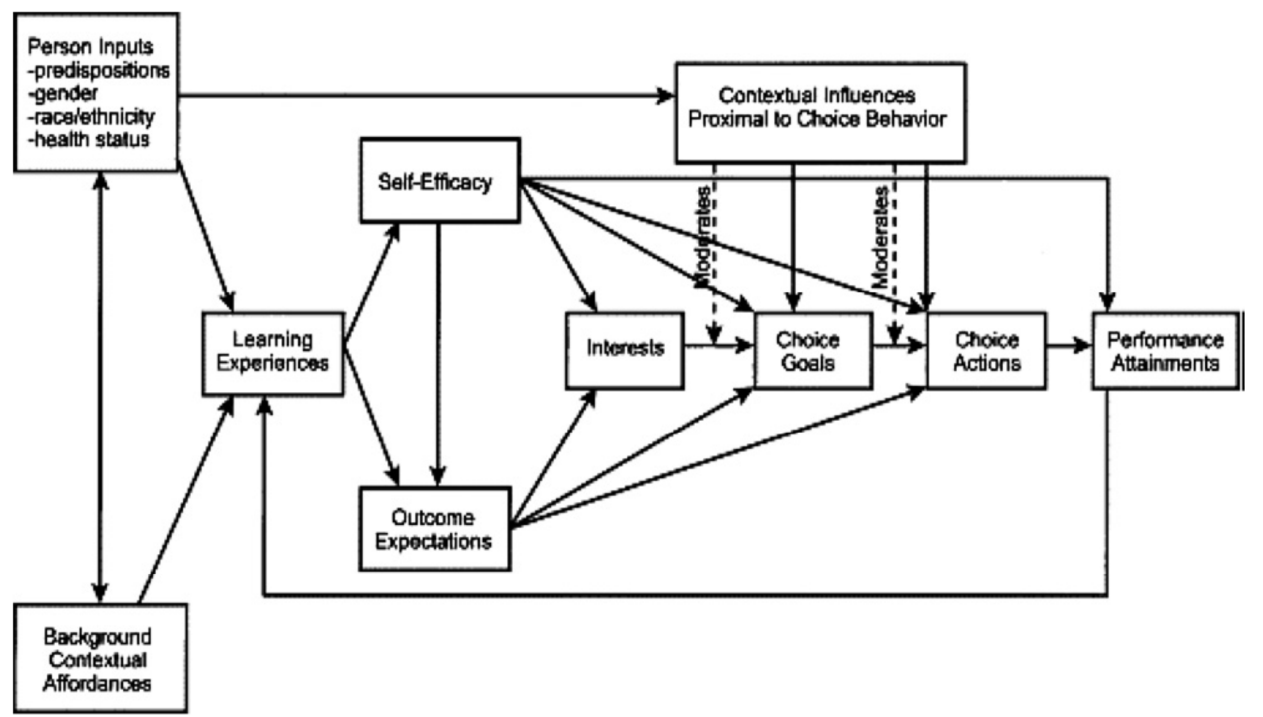

Figure 1. Flow chart of the social cognitive career theory (SCCT). Adopted from "Toward a unifying social cognitive theory of career and academic interest, choice, and performance”. By R.W. Lent, S. D. Brown, \& G. Hackett. (1994). Journal of Vocational Behavior, 45, p. 93 [26]. 


\subsection{The Social Influence Theory}

For an explanation on why social and political skill influences career outcome, some researchers [17, 28, 36] used the social influence theory. Social influence is an effort by an individual or group to change the attitudes, behaviors, or beliefs of others. It occurs when an individual's thoughts or actions are affected by other people intentionally or unintentionally. As a result, the changed person perceives themselves in relationship to the influencer, other people, and society in general. In addition, according to Levy [28], individuals use their certain social influence behaviors to achieve a desired positive career outcome. Individuals will influence others to attain this such as through desired roles, assignments, and rewards (e.g. compensation, performance appraisal, and promotions). Individuals who are high in political skill will better understand the interactions in the organization and will use that understanding to influence others. Todd et al.
[17], used the social influence theory to explain the relationship between political skill and career success.

\subsection{The Political Theory of Leadership}

The political theory of leadership could be used as a theoretical basis for studying career success from political perspective [32]. Ammeter, Douglas, Gardner, Hochwarter, \& Ferris, [29] proposed a political theory of leadership, which specifies that interpersonal qualities (e.g. social capital, cognition, political will, and personality) affects the political behavior utilized by a leader and affects the important individual-level outcomes of the leader such as leader effectiveness, performance evaluation, promotion, and, reputation. Specifically, a leaders' political behavior will increase his or her organizational power, increase his or her interpersonal reputation, and earn him or her greater organizational rewards. Leader outcome also influence by target outcome and antecedents.

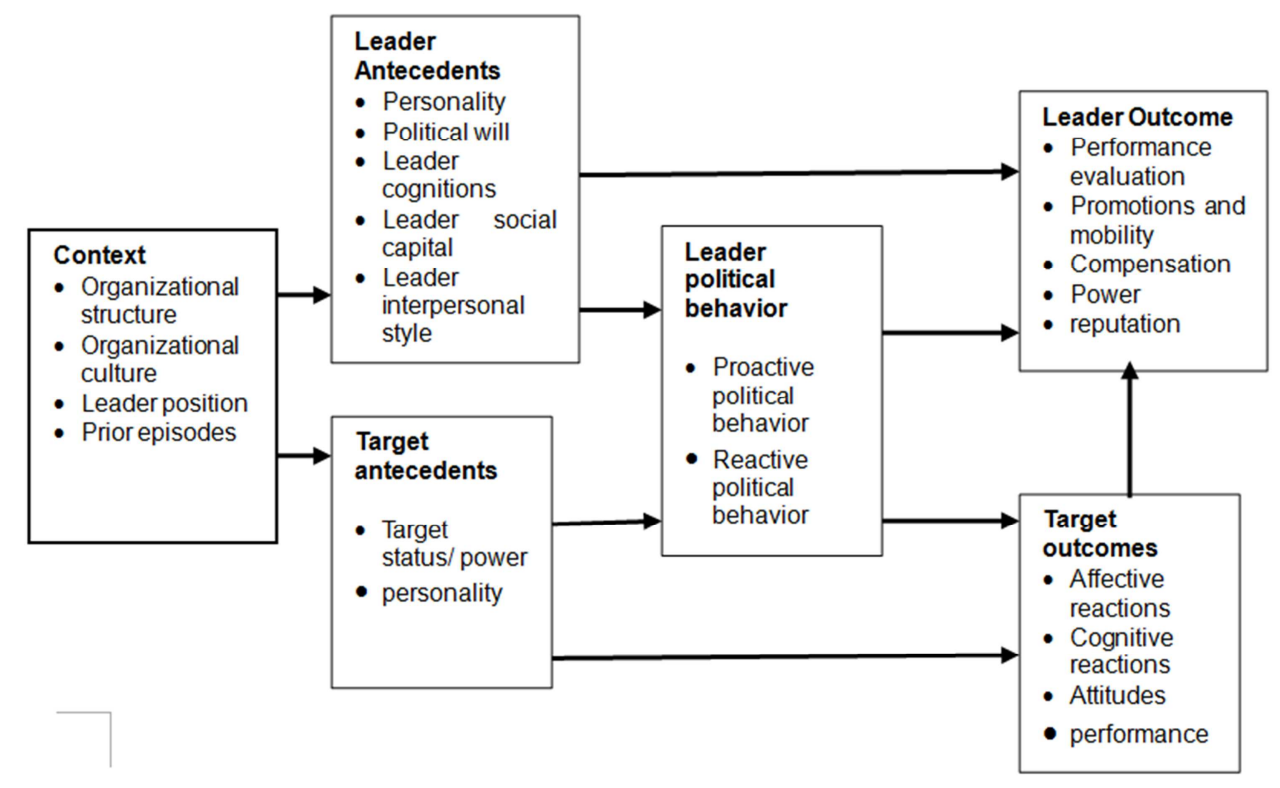

Figure 2. The political model of leadership. Adopted from "Toward a political theory of leadership" by A. P. Ammeter, C., Douglas, W. L., Gardner, W. A., Hochwarter, \& G. R., Ferris, (2002). Leadership Quarterly, 13, p.754 [29].

Table 2. Examples the study of career success and theoretical underpinning.

\begin{tabular}{|c|c|}
\hline $\begin{array}{l}\text { Career success } \\
\text { Underpinning Theory }\end{array}$ & Authors (year) \\
\hline \multirow[t]{3}{*}{ Human Capital Theory } & $\begin{array}{l}\text { Judge, T.A., Cable, D.M., Boudreau, J.W. \& } \\
\text { Bretz, R.D. (1995); }\end{array}$ \\
\hline & Aryee, S., Chay, Y. W. \& Tan, H. H. (1994) \\
\hline & Fang, T., Zikic, J., \& Novicevic, M.M. (2009) \\
\hline \multirow{5}{*}{ Social Capital Theory } & Dierendonck, D.V. , and Gaast, E.V , (2013) \\
\hline & Seibert, S.E., Crant, J.M \& Kraimer, M.L. (2001) \\
\hline & Roziah Mohd Rasdi, Thomas N. Garavan \\
\hline & Maimunah Ismail, (2013) \\
\hline & Nikitkov, A. and Sainty, B., (2014) \\
\hline $\begin{array}{l}\text { Career Congruence } \\
\text { Theory }\end{array}$ & Holland, J.L. (1997) \\
\hline $\begin{array}{l}\text { Super's theory of } \\
\text { Vocational Choice }\end{array}$ & Super, D. E. (1953) \\
\hline
\end{tabular}

\begin{tabular}{|c|c|}
\hline $\begin{array}{l}\text { Career success } \\
\text { Underpinning Theory }\end{array}$ & Authors (year) \\
\hline The mobility theory & $\begin{array}{l}\text { Hall, D.T. (1976) } \\
\text { Victor Y. Haines, Salima Hamouche, Tania } \\
\text { Saba , (2014) } \\
\text { Lyons, S.T., Schweitzer, L.,Ng, Eddy S.W, } \\
\text { (2015) }\end{array}$ \\
\hline $\begin{array}{l}\text { Social learning theory } \\
\text { (SLT) }\end{array}$ & Lau, V.P \& Shaffer, M.A. (1999). \\
\hline $\begin{array}{l}\text { Social Cognition Career } \\
\text { Theory (SCCT) }\end{array}$ & $\begin{array}{l}\text { Roziah Mohd Rasdi, Maimunah Ismail \& Jegak } \\
\text { Uli. (2009); }\end{array}$ \\
\hline $\begin{array}{l}\text { The social influence } \\
\text { theory }\end{array}$ & $\begin{array}{l}\text { Ochs, L., Roessler, R (2004) } \\
\text { Todd, S.Y., Harris, K.J., Harris, R.B, \& Wheeler, } \\
\text { A.R. (2009); } \\
\text { Hennekam, S. (2015) }\end{array}$ \\
\hline $\begin{array}{l}\text { The political theory of } \\
\text { leadership }\end{array}$ & Ishak, S (2011) [32] \\
\hline
\end{tabular}




\section{Conclusion}

This article described the concept, indicators and approach of career success study through a search of research literature. Based in literature review, the theories underpinning the previous career success studies have been briefly presented. This paper contributes to the literature by examine the different types of career theories fit on career success research. The field of career success studies continues to mature as an area of research. The study shows that there were no major theories that established and it applied inconsistently in the career success research. The choice of theory is depend on perspective selected by researcher.

\section{References}

[1] Judge, T.A., Cable, D.M., Boudreau, J.W. \& Bretz, R.D. (1995). An empirical investigation of the predictors of executive career success. Journal of Management, 48, 485-519.

[2] Aryee, S., Chay, Y. W. \& Tan, H. H. (1994). An examination of the antecedents of subjective career success among a managerial sample in Singapore, Human Relations, 47, 487-509.

[3] Nabi, G.R. (1999). An investigation into differential profile of predictors of objective and subjective career success. Career Development International, 4(4), 212-224.

[4] Nabi, G.R. (2003). Situational characteristics and subjective career success: The mediating role of career-enhancing strategies. International Journal of Manpower, 24(6), 653-673.

[5] Seibert, S.E., Crant, J.M \& Kraimer, M.L. (2001). What do proactive people do? A longitudinal model linking proactive personality and career success. Personnel Psychology, 54(4), 845 .

[6] Melamed, T. (1995). Career success: The moderating effect of gender. Journal of Vocational Behavior, 47, 35-60.

[7] Judge, T.A., \& Bretz, R.D. (1994). Political influence behavior and career success. Journal of management, 20(1), 43-65.

[8] Pachulicz, S., Schmitt, N., \& Kuljanin, G., (2008). A Model of Career Success: A Longitudinal Study of Emergency Physicans, Journal of Vocational Behavior, 10, 105-131.

[9] Bozionelos, N. (2003). Intra-organizational network resources: Relation to career success and personality. The International Journal of Organizational Analysis, 11, 41-66.

[10] Poon, J.M.L. (2004).Career commitment and career success: moderating role of emotion perception. Career Development International, 9(4/5), 374.

[11] Gattiker, U.E., \& Larwood, L. (1988). Subjective career success: A study of managers and support personnel. Journal of Business and Psychology, 1, 78-94.

[12] Lau, V.P \& Shaffer, M.A. (1999).Career success: The effect of personality. Career Development International, 4(4), 225.

[13] Nabi, G.R. (2001). The relationship between HRM, social support and subjective career success among men and women. International Journal of Manpower, 22(5), 457-474.
[14] Ng, T.W.H., Eby, L. T., Sorensen, K. L., \& Feldman, D. C. (2005). Predictors of objective and subjective career success. A meta-analysis. Personnel Psychology, 58, 367-408.

[15] Abele, A.E., \& Spurk, D. (2009). The longitudinal impact of self-efficacy and career goals on objective and subjective career success. Journal of Vocational Behavior, 74, 53-62.

[16] Byrne, Z.S., Dik, B.J., \& Chiaburu, D.S. (2008). Alternatives to tradional mentoring in fostering career success. Journal of Vocational Behavior, 72, 429-442.

[17] Todd, S.Y., Harris, K.J., Harris, R.B, \& Wheeler, A.R. (2009). Career success implications of political skill. Journal of Social Psychology, 149(3), 179-204.

[18] Becker, G.S. (1993), Human Capital (3rd ed.), Chicago, IL: University of Chicago Press.

[19] Fang, T., Zikic, J., \& Novicevic, M.M. (2009). Career success of immigrant professionals: Stock and flow of their career capital. International Journal of Manpower, 30(5), 472-488.

[20] Holland, J.L. (1997). Making vocational choices: A theory of vocational personalities and work environments ( ${ }^{\text {rd }}$ ed.). Odessa, Fl: Psychological Assessment Resources.

[21] Lin, Nan (2001). Social Capital: A Theory of Social Structure and Action. Cambridge University Press; NY, USA.

[22] Super, D. E. (1953). A theory of vocational development. American Psychologist, 8, 185-190.

[23] Hall, D.T. (1976). Career in Organization. Pacific Palisades, CA: Goodyear.

[24] Turner, R.J. (1960).Sponsored and contest mobility and school system. American Sociological Review, 25, 855-867.

[25] Bandura, A. (1977). Social Learning Theory. New York: Prentice-Hall.

[26] Lent, R. W., Brown, S.D., \& Hackett, G. (1994). Toward a unifying social cognitive theory of career and academic interest, choice, and performance. Journal of Vocational Behavior, 45, 79-122.

[27] Roziah Mohd Rasdi, Maimunah Ismail \& Jegak Uli. (2009). Towards developing a theoretical framework for measuring public sector managers' career success. Journal of European Industrial Training, 33(3), 232-254.

[28] Levy, P.E. (2003). Industrial/Organizational psychology understanding the workplace. Boston, MA: Houghton Mifflin Company.

[29] Ammeter, A. P., Douglas, C., Gardner, W. L., Hochwarter, W. A., \& Ferris, G. R. (2002). Toward a political theory of leadership. Leadership Quarterly, 13, 751-796.

[30] Victor Y. Haines, Salima Hamouche, Tania Saba, (2014) "Career success: fit or marketability?" Career Development International, Vol. 19 Iss: 7, pp.779- 793.

[31] Nikitkov, A. and Sainty, B., (2014) "The role of social media in influencing career success", International Journal of Accounting \& Information Management, Vol. 22 Iss: 4, pp. $273-294$.

[32] Ishak, Shahibudin (2011). The Influence of Personal Characteristics and Organizational Politics on Career Success of School Principals in Malaysia. Phd Thesis, UUM. 
[33] Dierendonck, D.V., and Gaast, E.V, (2013) "Goal orientation, academic competences and early career success", Career Development International, Vol. 18 Iss: 7, pp.694-711.

[34] Roziah Mohd Rasdi, Thomas N. Garavan, Maimunah Ismail, (2013) "Networking behaviours and managers' career success in the Malaysian public service: The moderating effect of gender", Personnel Review, Vol. 42 Iss: 6, pp.684-703.

[35] Lyons, S.T., Schweitzer, L.Ng, Eddy S.W., (2015). How have careers changed? An investigation of changing career patterns across four generations, Journal of Managerial Psychology, Vol. 30 (1): 1, pp. $8-21$.

[36] Hennekam, S. (2015) "Career success of older workers: the influence of social skills and continuous learning ability", Journal of Management Development, Vol. 34 Iss: 9, pp.
[37] Reimara Valk, Mandy Van der Velde, Marloes Van Engen, Rohini Godbole, (2014) "International career motives, repatriation and career success of Indian women in Science \& Technology", Journal of Global Mobility, Vol. 2 Iss: 2, pp.203 -233 .

[38] Robin Cheramie, (2013) "An examination of feedback-seeking behaviors, the feedback source and career success", Career Development International, Vol. 18 Iss: 7, pp.712 - 731 .

[39] Sophie Hennekam, (2015) "Career success of older workers: the influence of social skills and continuous learning ability", Journal of Management Development, Vol. 34 Iss: 9, pp.1113 -1133 .

[40] Talya N Bauer, Talya N. Bauer, Berrin Erdogan. The Oxford Handbook of Leader-Member Exchange. Oxford University Press, Sep 2015 - 456 pages. 